\title{
PREVALENCE OF PROLONGED QTC INTERVAL IN PATIENTS TAKING PSYCHOPHARMACS
}

\author{
Zoran Jovanovic ${ }^{1}$, Vesela Radonjic ${ }^{2}$, Ratomir Jelic ${ }^{2}$, Narcisa Petrovic-Subic ${ }^{3}$, Ivan Soldatovic ${ }^{1}$, Vera Terzic ${ }^{1}$, Sladjan Stojilkovic ${ }^{4}$, Dusan Djuric ${ }^{2}$ \\ ${ }^{1}$ General hospital Sabac, Department of Psychiatry, Republic of Serbia \\ ${ }^{2}$ Department of pharmacy, Faculty of medical sciences, Kragujevac, Republic of Serbia \\ ${ }^{3}$ Hemofarm A.D. Vršac, Serbia, \\ ${ }^{4}$ Society of external and internal export Medicom, Sabac, Republic of Serbia \\ ZASTUPLJENOST PRODUŽENOG QTC INTERVALA \\ KOD PACIJENATA KOJI UZIMAJU PSIHOFARMAKE

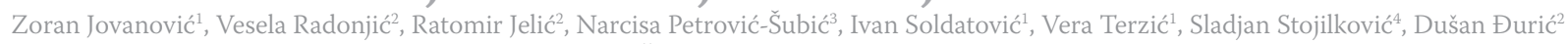 \\ ${ }^{1}$ Opšta bolnica Šabac, Služba psihijatrije, Republika Srbija \\ ${ }^{2}$ Katedra za farmaciju, Fakultet medicinskih nauka, Kragujevac, Republika Srbija \\ ${ }^{3}$ Hemofarm A.D, Republika Srbija \\ ${ }^{4}$ Društvo za spoljnu i unutrašnju trgovinu Medicom d.o.o. Šabac, Republika Srbija
}

Received / Primljen: 15. 08. 2016.

Accepted / Prihvaćen: 05. 12. 2016.

\begin{abstract}
Apart from providing knowledge on the beneficial effects of drugs, practical psychopharmacotherapy also includes drug profiles of adverse effects, especially when medical comorbidity is present. The mechanism of action of many psychotropic drugs, mainly antipsychotics and antidepressants, is associated with prolongation of the QT interval and the occurrence of arrhythmias, specifically Torsade de pointes (TdP), which can be lethal. The aim of this pilot study was to confirm the prevalence of prolonged QTc interval in a sample of psychiatric patients taking psychopharmacs.

The present study included 41 patients who were already on psychopharmacs. The average value of the QTc interval in the observed sample was $413.8 \pm 23.3 \mathrm{~ms}$. The most frequent psychopharmacotherapy was the combination of typical and atypical antipsychotics (24.4\%), followed by monotherapy with antipsychotics (22\%) and combined antidepressant and atypical antipsychotic therapy (22\%). The average value of the QTc interval for male patients was $412.1 \pm 25.2 \mathrm{~ms}$, whereas for female patients, it was $416.6 \pm 20.4 \mathrm{~ms}$. No difference between sexes was confirmed ( $p=0.555)$. The correlation between the QTc interval and age of patients was positive but not statistically significant $(p=0.072)$. The highest average $(419.3 \pm 31.6$ $\mathrm{ms}$ ) and highest maximum $(479 \mathrm{~ms})$ values of the QTc interval were noted for patients undergoing combined therapy of antidepressants and atypical antipsychotics. Prolonged values of the QTc interval were observed for seven males and one female, and no patients exhibited pathological values.

This study confirmed previous research that found that prolongation of the QTc interval exists in patients in sample groups who take psychopharmacs, but not up to critical values.
\end{abstract}

Keywords: psychopharmacs, antidepressants, antipsychotics, prolonged QTc interval, Torsade de pointes

\section{SAŽETAK}

Racionalna psihofarmakoterapija podrazumeva osim dobrog poznavanja blagotvornih efekata lekova $i$ njihov profil neželjenih dejstava, posebno kada postoji somatski komorbiditet. Mnogi psihotropni lekovi, prvenstveno antipsihotici $i$ antidepresivi, povezani su sa produženjem QT intervala $i$ nastankom aritmija tipa Torsade de pointes (TdP), što se može završiti letalno. Cilj ove pilot studije bio je da, kod posmatrane grupe psihijatrijskih pacijenata koji uzimaju psihofarmake, utvrdimo zastupljenost produženog QTc inervala.

U ispitivanje je uključen 41 bolesnik, koji već koriste psihofarmake u terapiji. Naše istraživanje je pokazalo da je prosečna vrednost QTc intervala u posmatranom uzorku iznosila 413,8 23,3 ms. Najčešće je primenjivana kombinacija tipičnog $i$ atipičnog antipsihotika (24,4\%), sledi monoterapija antipsihotikom $i$ kombinovana terapija antidepresiv-atipični antipsihotik sa po $22 \%$. Prosečna vrednost QTc

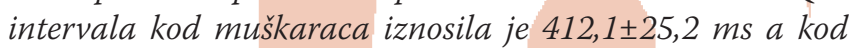

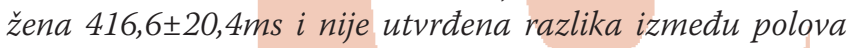
$(p=0,555)$. Korelacija QTc intervala i starosti pacijenata bila je pozitivna ali nije statistički značajna $(p=0,072)$. Najviše prosečne $(419,3 \pm 31,6 \mathrm{~ms})$ kao i maksimalne (479ms) yrednosti QTc intervala uočene su kod pacijenata na kombinovanoj terapiji antidepresiv $i$ atipični antipsihotik. Produžene vrednosti QTc intervala registrovane su kod sedam bolesnika $i$ kod jedne bolesnice dok patoloških vrednosti u posmatranom uzorku nije bilo.

Ova studija potvrdila je prethodna saznanja da prolongacija QTc intervala postoji kod pacijenata u našem uzorku koji uzimaju psihofarmake, ali ne $i$ do kritičnih vrednosti.

Ključne reči: psihofarmaci, antidepresivi, antipsihotici, produžen QTc interval, Torsade de pointes 


\section{INTRODUCTION}

The complexity of mental disorders is apparent not only in their primary symptoms but also in the adverse effects of available pharmacotherapies. Oftentimes, the adverse symptoms are not noticed in a timely manner due to the patients' altered psychological functioning, negligence of their own health and ascribing iatrogenic symptoms to a disease itself (1-3). Although new psychopharmacs generally have fewer adverse effects, we are still not satisfied with the level of efficacy and safety (4). Furthermore, psychiatric patients are likely to abuse psychoactive substances and experience drug overdose, which makes the clinical picture more complex and significantly changes the bioavailability of psychotropic drugs $(5,6)$. Given the above complications, psychopharmacs are a cause of many adverse events and have the potential for interactions with drugs of other categories (4).

Although rare, iatrogenic cardiovascular disorders are amongst the most serious adverse events and mainly include heart rhythm disorders and sudden cardiac death (7, 8). Many psychopharmacs, especially antipsychotics and antidepressants, are associated with prolongation of the QT interval and the occurrence of arrhythmia, specifically the type Torsade de pointes (TdP), which can be lethal (9, 10). The QT interval on an electrocardiogram represents the time interval from the beginning of the $\mathrm{Q}$ wave to the end of the $T$ wave, i.e., it corresponds to the start of activation (depolarization) and the end of recovery (repolarization) of the ventricles. Its physiological values are variable due to the influence of heart rate, age and sex, thus, as a more precise electrophysiological value, the corrected value QTc interval is used (11). Normal values of QTc interval for males reach up to $430 \mathrm{~ms}$, borderline values range from $431 \mathrm{~ms}$ to $450 \mathrm{~ms}$, and pathological values are $>450$ $\mathrm{ms}$; whereas for females, normal values reach up to $450 \mathrm{~ms}$, borderline values range from $451 \mathrm{~ms}$ to $470 \mathrm{mg}$ and pathological values are $>470 \mathrm{~ms}$ (12). Prolongation of the QTc value above $500 \mathrm{~ms}$ for both sexes is not always accompanied by arrhythmia, but it significantly increases the risk of TdP occurrence, in other words, sudden cardiac death (13).

The potential for prolongation of the QT interval by psychopharmacs was first noticed with phenothiazines, mostly with thioridazine (approximately $36 \mathrm{~ms}$ ), and therefore, it was generally withdrawn from the market. However, thioridazine is still administered in some countries under specific circumstances (14). Subsequently, numerous studies confirmed that many other antipsychotics can variably prolong the QT interval, such as pimozide, chlorpromazine, haloperidol and droperidol; however, more recent drugs, such as sertindole, quetiapine, ziprasidone, risperidone, etc., can also prolong the QT interval $(15,16)$. In addition, the same effect was noticed with methadone (17), lithium and different antidepressants, including tri- and tetra-cyclic antidepressants and SSRI/SNRI [(es)citalopram, fluoxetine, venlafaxine, etc.] (16). Additional factors that can increase the risk of prolonged QT interval include inborn prolongation of the QT interval, comorbid cardiac and other medical diseases, anorexia, electrolyte imbalance, simultaneous intake of other drugs that prolong QT interval or interact with psychopharmacs, age older than 65 years, female sex and positive familial anamnesis of sudden cardiac death $(18,19)$. For this reason, testing is required on the pro-arrhythmogenic potential of drugs, i.e., their the influence on QT/QTc interval, during pre-clinical and clinical trials of these drugs $(20,21)$.

The aim of this pilot study was to confirm the prevalence of prolonged QTc interval in a group of psychiatric patients who take psychopharmacs.

\section{PATIENTS AND METHODOLOGY}

This cross-sectional study used data from 41 hospitalized patients in the psychiatric ward of the General Hospital in Sabac after obtaining informed consent. The sample involved patients of both sexes, aged 24 to 80 years old, who were already taking psychopharmacs. The patients were stratified into five groups depending on whether they took antidepressant monotherapy, atypical/typical antipsychotic therapy, combined therapy with antidepressant/ antipsychotic or substitutional methadone therapy in the last seven days. The observed groups underwent additional therapy of benzodiazepine and/or psychostabilizers. All the patients underwent a standard 12-lead electrocardiogram (ECG). Only ECGs of technical quality that did not register disorders of conduction of the His bundle (block/ chemiblock), ST segments or T waves were considered. The exclusion criteria for this study were patients who took neuropsychiatric drugs, which, according to the relevant references, can extend the QTc interval $(22,23)$. The basic psychiatric diagnoses of the participants were given in accordance with the International Classification of Disease $-10^{\text {th }}$ revision (ICD-10).

The length of the QT interval depends on the patient's sex and heart rate. The value of the QTc interval is expressed in milliseconds (ms) and the obtained results, according to the valid international criteria (12), were classified into six intervals: normal values for men up to $430 \mathrm{~ms}$, normal values for women up to $450 \mathrm{~ms}$, borderline values for men up to 431-450 ms, borderline values for women up to $451-470 \mathrm{~ms}$, pathological values for men $>450 \mathrm{~ms}$ and pathological values for women $>470 \mathrm{~ms}$. For all patients, the corrected QT interval (QTc) was calculated according to Bazett's formula, in which the value of the QT interval (QT) is divided by the square root of the length between two consecutive $\mathrm{R}$ waves $(\mathrm{QTc}=\mathrm{QT} / \sqrt{\mathrm{R} R})$. In order to determine the end of the T wave in unclear ECGs, the QT interval was calculated using the tangent method in cycles where the $\mathrm{T}$ wave was best defined.

The results are presented as arithmetic means +/- standard deviations or as a number (percentage). The t-test and ANOVA were used to test the significance of the differences in numerical observations, whereas the Chi square test 
Table 1 The comparison of the QTc interval by sex of patients taking psychopharmacs

\begin{tabular}{|l|c|c|c|c|c|}
\hline Sex & $\begin{array}{c}\text { Arithmetic mean } \\
\text { QTc }\end{array}$ & SD & Median & Minimum \\
\hline Male & 412.1 & 25.2 & 413.0 & 360 & 462 \\
\hline Female & 416.6 & 20.4 & 408.5 & 389 & 479 \\
\hline
\end{tabular}

was used to examine the significance of differences among groups concerning nominal observations. Pearson correlation analysis was used to examine the correlation between two numerical variables. All the results were processed using SPSS 20.0 (IBM corporation) software package.

\section{RESULTS}

The observed group included 41 patients, consisting of 25 males (61\%) and 16 (39\%) females, with an average age of $51.3 \pm 14.4$ years. The average age of male patients was 50.2 years, whereas the average age of female patients was 53.2 years; there was no statically significant difference in age between sexes $(\mathrm{p}=0.509)$. The average value of the QTc interval in the observed sample was $413.8 \pm 23.3 \mathrm{~ms}$ with a range of $360 \mathrm{~ms}$ to $479 \mathrm{~ms}$. The most common diagnoses were various schizophrenic disorders in $48.7 \%$ of patients [i.e., schizophrenia (F20) $36.6 \%$, schizoaffective disorder (F25) 7.3\%, brief psychotic disorder (F23) 2.4\% and unspecified psychosis (F29) 2.4\%]. Other diagnoses were affective disorders in $36.6 \%$ of patients [i.e., recurrent depressive disorder (F33) $24.4 \%$, single episode of depressive disorder (F32) $9.6 \%$, and bipolar affective disorder (F31) 2.4\%], chronic psychoorganic syndrome (F06) in $9.8 \%$ of patients, and dementia (F03) and opioid-related disorders (F11) in $2.4 \%$ of patients. Regarding pharmacotherapy, most pa- tients were taking a combination of typical and atypical antipsychotics (24.4.\%), followed by monotherapy of antipsychotic (22\%), combined therapy of antidepressant - atypical antipsychotic (22\%), monotherapy of antidepressant $(17.1 \%)$, typical antipsychotic $(12.2 \%)$ and substitutional methadone therapy $(2.4 \%)$.

In Table 1, the values of the QTc interval by patient sex are presented. The average value for males is $412.1 \pm 25.2$ $\mathrm{ms}$, whereas for females the average value is $416.6 \pm 20.4$ $\mathrm{ms}$. There was no statistically significant difference in QTc interval between sexes $(t=0.596 ; \mathrm{p}=0.555)$.

The correlation between QTc interval and age was weak to moderately positive but not statistically significant $(\mathrm{r}=0.284 ; \mathrm{p}=0.072)$ (Graphic 1). The highest independent value of $479 \mathrm{~ms}$ for the QTc interval was recorded in a 46-year-old female patient.

The relationship between pharmacotherapy and the values of the QTc intervals were analysed. The average QTc values by medications are shown in Table 2. The highest average QTc interval $(419.3 \pm 31.6 \mathrm{~ms})$ and the overall maximal value $(479 \mathrm{~ms})$ were noted in the group of patients undergoing combined therapy of an antidepressant and an atypical antipsychotic. When excluding the one patient taking methadone therapy, there was no statistically significant difference between the duration of the QTc interval by administered therapy, regardless of whether it was monotherapy or a combination of psychopharmacs $(\mathrm{F}=0.522 ; \mathrm{p}=0.720)$.

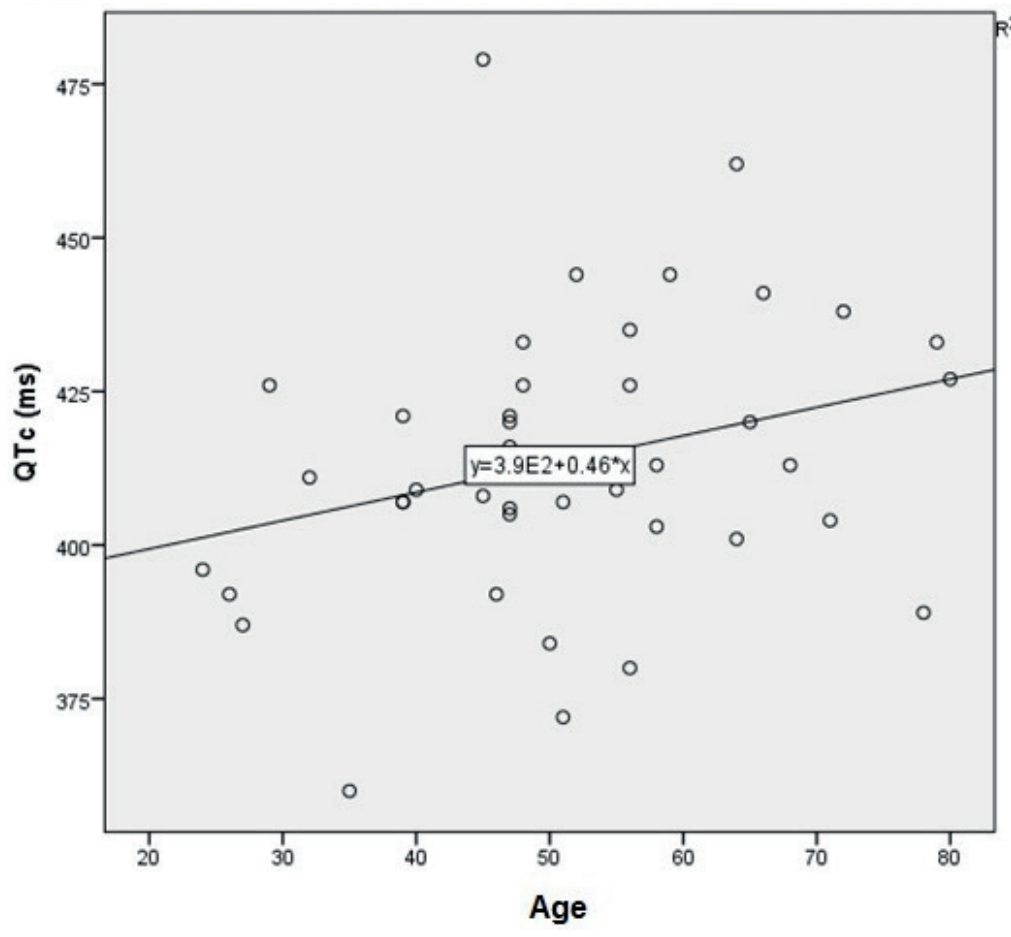

Graphic 1 The correlation between QTc interval and age of the patients taking psychopharmacs 
Table 2 The comparison of the values of the QTc interval according to pharmacotherapeutic group

\begin{tabular}{|l|c|c|c|c|}
\hline Th & $\begin{array}{c}\text { Arithmetic mean } \\
\text { QTc }\end{array}$ & SD & Median & Minimum \\
\hline Antidepressant & 405.0 & 20.1 & 401.0 & 380 \\
\hline Typical antipsychotic & 406.6 & 21.2 & 404.0 & 433 \\
\hline Atypical antipsychotic & 416.0 & 10.3 & 413.0 & 441 \\
\hline Antidepressant + atypical antipsychotic & 419.3 & 31.6 & 420.0 & 407 \\
\hline $\begin{array}{l}\text { Typical antipsychotic +atypical } \\
\text { antipsychotic }\end{array}$ & 417.0 & 28.7 & 414.0 & 360 \\
\hline Methadone & 411.0 &. & 411.0 & 479 \\
\hline
\end{tabular}

Box-plot Diagram 1 shows the distribution of the QTc interval depending on the type of psychopharmacotherapy.

The measured values of the QTc interval were, in accordance with the valid international criteria (12), classified in six intervals: normal values for men up to $430 \mathrm{~ms}$, normal values for women up to $450 \mathrm{~ms}$, borderline values for men 431-450 ms, borderline values for women 451-470 ms, pathological values for men $>450 \mathrm{~ms}$ and pathological values for women $>470 \mathrm{~ms}$. Prolonged values were noted for 7 male patients and one female patient, but there were no patients with pathological values. There was no statistically significant difference in QTc interval categories between sexes $(\mathrm{p}=0.120)$ (Table 3).

In addition, the correlation between the abovementioned QTc categories and administered psychotropic drugs was analysed. According to the statistical parameters, the sample was too small for such a large number of categories. When one patient undergoing methadone therapy was excluded, it was confirmed that there was no statistically significant difference between the observed QTc categories and the administered psychotropic drugs
Table 3 QTc interval categories by sex of the patients taking psychopharmacs

\begin{tabular}{|l|l|l|l|l|}
\hline Values QTc & & & & \\
\hline Sex & & Normal & Higher & Total \\
\hline Male & N & 18 & 7 & 25 \\
\hline & $\%$ & $72.00 \%$ & $28.00 \%$ & $100.00 \%$ \\
\hline Female & $\mathrm{N}$ & 15 & 1 & 16 \\
\hline & $\%$ & $93.80 \%$ & $6.30 \%$ & $100.00 \%$ \\
\hline
\end{tabular}

$(\mathrm{p}=0.310)$. The exact test was used for this analysis. On an individual basis, in one 46-year-old female patient who was administered clomipramine $150 \mathrm{mg}$ in combination with atypical antipsychotic quetiapine $600 \mathrm{mg}$ per day, the QTc interval was $479 \mathrm{~ms}$. For the seven male patients with QT prolongation, a maximum QTc interval of $462 \mathrm{~ms}$ was recorded, and all of them were administered different drug categories. Four of these patients took combined therapy chlorpromazine in dosages from 50 to $150 \mathrm{mg}$. The relationship between pharmacotherapy and QTc interval values is shown in Table 4.

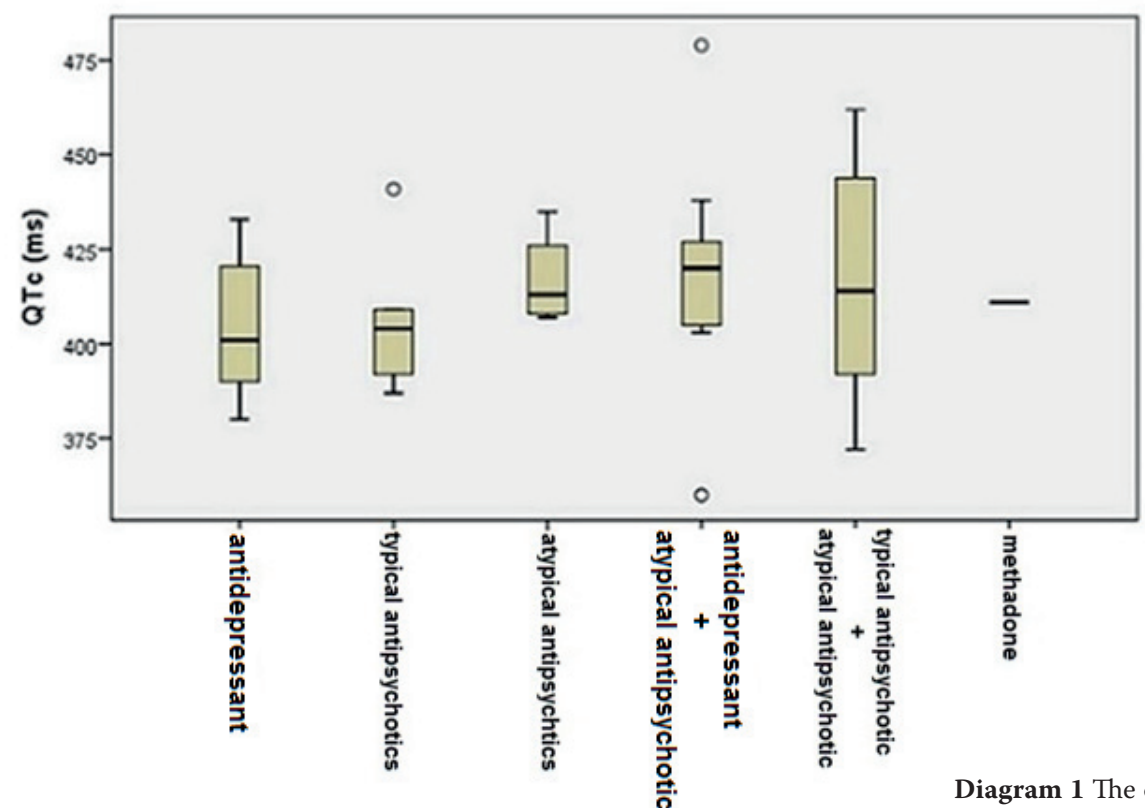

ing to pharmacotherapeutic group 
Diagram 2 QTc intervals according to pharmacotherapeutic groups

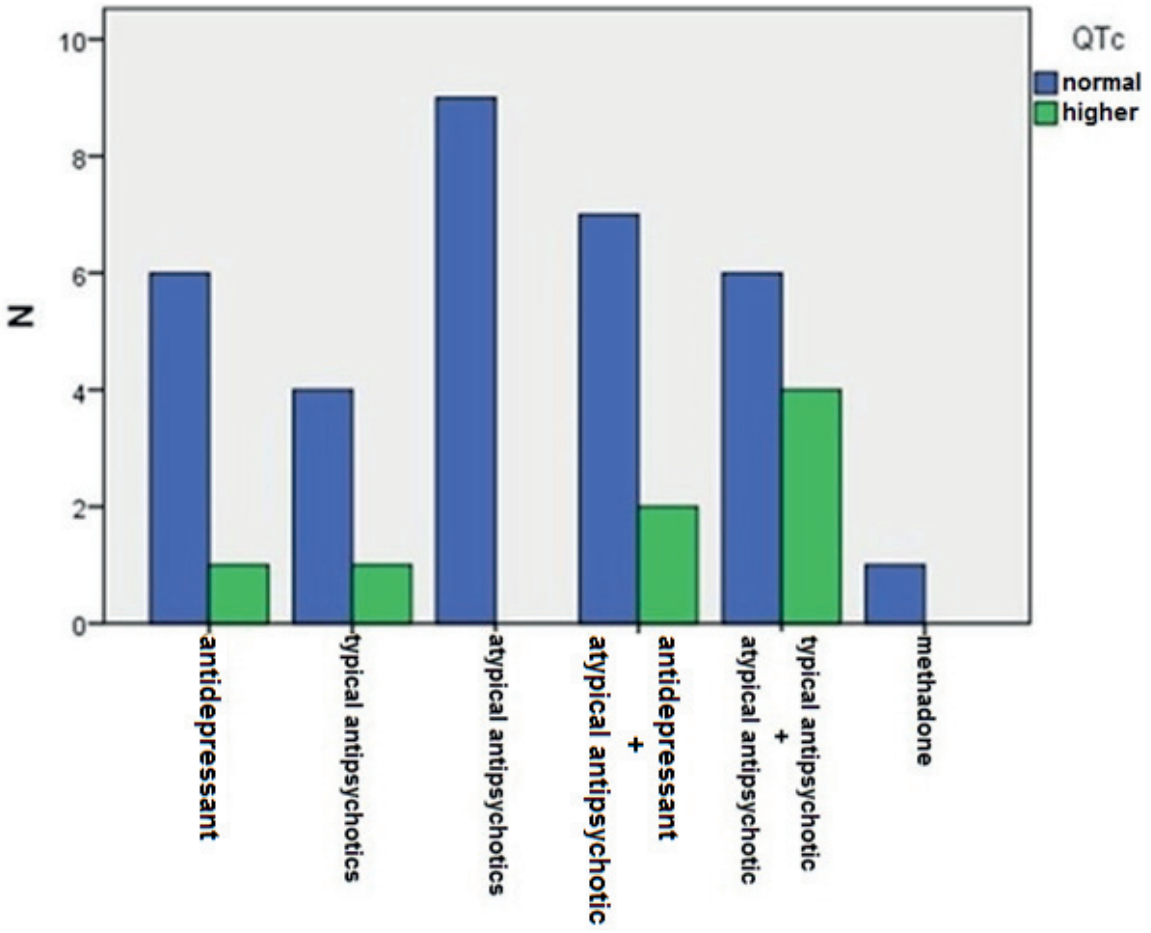

\section{DISCUSSION}

Diagram 2 shows that the prolonged value of the QTc interval was mostly present in patients taking combined therapy of typical and atypical antipsychotics, followed by combined therapy of antidepressant and atypical antipsychotic. However, QTc prolongation was less prominent in monotherapy using an antidepressant and an atypical antipsychotic.
In this pilot study, participants of both sexes were included equally. In addition, the geriatric population with mental problems was also present, since, in our society, they are often hospitalized at psychiatric wards, at least at the secondary level. The most common were patients who suffer from disorders of the schizophrenia spectrum (F20F29), followed by affective disorders (F31-F33), chronic

Table 4 The comparison QTc interval categories according to the pharmacotherapeutic groups

\begin{tabular}{|c|c|c|c|c|}
\hline QTc categories & & & & \\
\hline Th & & Normal & Higher & Total \\
\hline \multirow{2}{*}{ Antidepressant } & $\mathrm{N}$ & 6 & 1 & 7 \\
\hline & $\%$ & $85.70 \%$ & $14.30 \%$ & $100.00 \%$ \\
\hline \multirow{2}{*}{$\begin{array}{l}\text { Atypical } \\
\text { antipsychotics }\end{array}$} & $\mathrm{N}$ & 4 & 1 & 5 \\
\hline & $\%$ & $80.00 \%$ & $20.00 \%$ & $100.00 \%$ \\
\hline \multirow{2}{*}{$\begin{array}{l}\text { Atypical } \\
\text { antipsychotics }\end{array}$} & $\mathrm{N}$ & 9 & 0 & 9 \\
\hline & $\%$ & $100.00 \%$ & $0.00 \%$ & $100.00 \%$ \\
\hline \multirow{2}{*}{$\begin{array}{l}\text { Antidepressant+atypical anti- } \\
\text { psychotic }\end{array}$} & $\mathrm{N}$ & 7 & 2 & 9 \\
\hline & $\%$ & $77.80 \%$ & $22.20 \%$ & $100.00 \%$ \\
\hline \multirow{2}{*}{$\begin{array}{l}\text { Typical antipsychotic + atypical } \\
\text { antipsychotic }\end{array}$} & $\mathrm{N}$ & 6 & 4 & 10 \\
\hline & $\%$ & $60.00 \%$ & $40.00 \%$ & $100.00 \%$ \\
\hline \multirow{2}{*}{ Methadone } & $\mathrm{N}$ & 1 & 0 & 1 \\
\hline & $\%$ & $100.00 \%$ & $0.00 \%$ & $100.00 \%$ \\
\hline
\end{tabular}


psychoorganic syndrome (F06) and dementia (F03), which required hospital treatment due to the complexity of the clinical picture.

Our patients did not show prolongation of QTc interval above the critical value of $500 \mathrm{~ms}$, which, according to all current recommendations, would be a reason to change pharmacotherapy (10). Nevertheless, there is no data on the values of the QTc interval in psychiatric patients before psychopharmacs were introduced. Therefore, it was not possible to calculate whether and to what extent there was prolongation of QTc interval, especially more than $60 \mathrm{~ms}$, in comparison to a baseline value. Although there were no statistically significant differences, the average value of the QTc interval for male patients was lower than the average values for female patients $(412.1 \pm 25.23 \mathrm{~ms} v s .416 .6 \pm 20.4$ $\mathrm{ms})$, which is in accordance with previous research. The shorter QTc for male patients compared to female patients can be explained by a quicker start of repolarization in male patients. This gender-specific difference decreases with age and is probably caused by the effects of testosterone on calcium current (25). Contrary to the abovementioned findings, in our sample, prolongation of the QTc interval was noted for seven male patients and one female patient. Comparing the age and the QTc values, a weak to average correlation between QTc interval and age of the patients was confirmed. Although a significant difference was not noted for ventricular repolarization by pharmacotherapeutic group, the highest value of QTc interval $(419.3 \pm 31.6 \mathrm{~ms})$ was observed in patients who were taking a combination of antidepressants and atypical antipsychotics; slightly lower values of QTc intervals were observed for patients who were on monotherapy of an antidepressant or an antipsychotic. These results are equal to other published research (26), though many authors confirm a significantly higher risk of prolongation of QTc interval with psychopharmacs polytherapy (27). Although a statistically significant difference was not confirmed, an analysis of the relationship between administered monotherapy or combination of drugs and QTc categories led to almost identical results. In the $40 \%$ of patients taking a combination of typical and atypical antipsychotics, prolongation of the QTc interval was confirmed, as well as in the $22.2 \%$ of patients on a combination of an antidepressant and an atypical antipsychotic. This finding can be explained by the additive effect of these drugs on ventricular repolarization. To emphasize, the combinations of drugs with high potential for prolongation of QTc values should be avoided when possible, especially in patients with other known risk factors $(18,19)$. Relevant research shows that the greatest negative effect is observed with phenothiazines (thioridazine $36 \mathrm{~ms}$, pimozide $19 \mathrm{~ms}$ ), followed by sertindole $30 \mathrm{~ms}$, ziprasidone $15.9 \mathrm{~ms}$, haloperidol $7.1 \mathrm{~ms}$, quetiapine $5.7 \mathrm{~ms}$ and risperidone $3.6 \mathrm{~ms}(28,29)$. With regard to clozapine, the results of this study are conflicting, but its cardiotoxic potential is unquestionable (30). Among antidepressants, mainly the adverse effects of tricyclic and tetracyclic were recorded (clomipramine, maprotiline, nortriptyline, ami- triptyline), as well as the dosage-additive potential of citalopram (18.5 ms in dosages of $60 \mathrm{mg} /$ day) and escitalopram (10.7 $\mathrm{ms}$ in dosages of $30 \mathrm{mg} /$ day) (31). The study also suggests clinically significant effect of recent drugs, such as venlafaxine, especially in dosages more than $300 \mathrm{mg}$ per day, and bupropion. Furthermore, research thus far has also confirmed the adverse influence of methadone substitutional therapy on QTc values (32).

\section{STUDY LIMITATIONS}

The main drawback of the study was that the number of patients in the present study was rather small compared to the data from the available literature. Other limitations include the lack of more precise exclusion criteria according to cardiology and general practice guidelines, laboratory analyses and baseline values of the QTc interval before administration of psychopharmacs. With more strict exclusion criteria, it would be possible to avoid potential influence of other factors on repolarization of ventricles, not only those accounted for by physical examination in psychiatric practice, anamnesis of somatic diseases and patients not taking neuropsychiatric drugs. In addition, there are also deviations of basic values during drug administration. The question of a valid determination of QTc interval can be raised concerning this and concerning broader research that has been carried out so far. Namely, the international research carried out by Viskin and associates (33) showed that most medical doctors (25\%), including many cardiologists, cannot precisely calculate QTc and cannot accurately identify prolonged QT. In addition, agitation of patients can influence electrolyte balance, i.e., cause hypokalemia, which would additionally change ventricular repolarization (34). Circadian changes and even consumption of certain foods, beverages and supplements can also influence values of QTc $(35,36)$. Additionally, the complexity of the problem is caused by various recommendations concerning the time of recording the ECG, where most experts recommend recordings 12 hours after drug administration or 30 to 60 minutes after its peak blood concentration is achieved $(37,38)$.

\section{CONCLUSION}

Prolongation of the QTc interval caused by psychopharmacs, mainly antipsychotics and antidepressants, is a relatively rare but severe event that can be lethal. Since administration of psychotropic drugs in daily practice is inevitable, an integrative approach to patients is necessary to avoid this kind of adverse event and to react effectively in such cases This strategy means knowing the mechanisms of action of a drug and methods of individual assessment of all the mentioned risks and, if necessary, the ability to interpret electrolytes and ECGs. The balance among the risks and positive effects of psychopharmacs is a great 
challenge, especially in our society where a psychiatrist is very often "a general practitioner" who also takes care of the general health of his/her patients.

Taking into consideration all the abovementioned limitations, this study showed that prolongation of the QTc interval exists in patients in our society who take psychopharmacs, but it does not lead to critical, i.e., torsadogenic, values.

To decrease the incidence of psychotropic-related QT prolongation, it is necessary to conduct further and broader clinical and pre-clinical research.

\section{REFERENCES}

1. Kang SH, Lee JI. Metabolic disturbances independent of body mass in patients with schizophrenia taking atypical antipsychotics. Psychiatry Investig. 2015; 12(2):242-8.

2. Rouillon F, Van Ganse E, Vekhoff P, Arnaud R, DepretBixio L, Dillenschneider A. Vigilance level for cardiovascular risk factors in schizophrenic patients. Encephale. 2015;41(1):70-7.

3. Cradock-O'Leary J, Young AS, Yano EM, Wang M, Lee ML. Use of general medical services by VA patients with psychiatric disorders. Psychiatr Serv. 2002;53(7):874-8.

4. Jones ME, Campbell G, Patel D, Brunner E, Shatapathy CC, Murray-Thomas T, van Staa TP, Motsko S. Risk of Mortality (including Sudden Cardiac Death) and Major Cardiovascular Events in Users of Olanzapine and Other Antipsychotics: A Study with the General Practice Research Database. Cardiovasc Psychiatry Neurol. 2013;2013:647476.

5. Tolliver BK, Anton RF. Assessment and treatment of mood disorders in the context of substance abuse. Dialogues Clin Neurosci. 2015;17(2):181-90.

6. Mowry JB, Spyker DA, Cantilena LR Jr, McMillan N, Ford M.2013 Annual Report of the American Association of Poison Control Centers' National Poison Data System: 31th Annual Report. Clin Toxicol. 2014;52:1032-283.

7. Weeke P, Jensen A, Folke F, Gislason GH, Olesen JB, Fosbøl EL, Wissenberg M, Lippert FK, Christensen EF, Nielsen SL, Holm E, Kanters JK, Poulsen HE, Køber L, Torp-Pedersen C. Antipsychotics and associated risk of out-of-hospital cardiac arrest. Clin Pharmacol Ther. 2014;96(4):490-7.

8. Nezafati MH, Vojdanparast M, Nezafati P. Antidepressants and cardiovascular adverse events: A narrative review. ARYA Atheroscler. 2015;11(5):295-304.

9. Zemrak WR, George A. Kenna GA. Association of Antipsychotic and Antidepressant Drugs With Q-T interval Prolongation. Am J Health Syst Pharm. 2008;65(11):1029-1038.

10. Hasnain M, Vieweg WV. QTc interval prolongation and torsade de pointes associated with second-generation antipsychotics and antidepressants: a comprehensive review. CNS Drugs. 2014;28(10):887-920.
11. Postema PG, Wilde AA. The Measurement of the QT Interval. Current Cardiology Reviews. 2014;10(3):287-294.

12. Committee for Proprietary Medicinal Products. The assessment of the potential for QT interval prolongation by non-cardiovascular medicinal products, Committee for Proprietary Medicinal Products, London (1997).

13. De Bruin ML, Langendijk PN, Koopmans RP, Wilde AA, Leufkens HG, Hoes AW. In-hospital cardiac arrest is associated with use of non-antiarrhythmic QTc-prolonging drugs. Br J Clin Pharmacol. 2007;63:216-223.

14. Huffman JC, Stern TA. QTc Prolongation and the Use of Antipsychotics: A Case Discussion. Prim Care Companion J Clin Psychiatry. 2003;5(6):278-281.

15. Vieweg WV. New Generation Antipsychotic Drugs and QTc Interval Prolongation.Prim Care Companion J Clin Psychiatry. 2003;5(5):205-215.

16. Girardin FR, Gex-Fabry M, Berney P, Shah D, Gaspoz JM, Dayer P. Drug-induced long QT in adult psychiatric inpatients: the 5-year cross-sectional ECG Screening Outcome in Psychiatry study. Am J Psychiatry. 2013;170(12):1468-76.

17. Wenzel-Seifert K, Wittmann M, Haen E. QTc Prolongation by Psychotropic Drugs and the Risk of Torsade de Pointes. Dtsch Arztebl Int. 2011; 108(41): 687-693.

18. Alinejad S, Kazemi T, Zamani N, Hoffman RS, Mehrpour O. A systematic review of the cardiotoxicity of methadone. EXCLI J. 2015;14:577-600.

19. Danielsson B, Collin J, Jonasdottir Bergman G, Borg N, Salmi P, Fastbom J. Antidepressants and antipsychotics classified with torsades de pointes arrhythmia risk and mortality in older adults - a Swedish nationwide study. Br J Clin Pharmacol. 2016;81(4):773-83.

20. Drew BJ, Ackerman MJ, Funk M, et al. Prevention of Torsade de Pointes in Hospital Settings: A Scientific Statement From the American Heart Association and the American College of Cardiology FoundationEndorsed by the American Association of Critical-Care Nurses and the International Society for Computerized Electrocardiology. Circulation. 2010;121(8):1047-1060.

21. Anonymous (2005b). International Conference on Harmonisation; guidance on S7b Nonclinical evaluation of the Potential for Delayed Ventricular Repolarization (QT Interval Prolongation) by Human Pharmaceuticals; availability. Notice. Fed Regist 70:61133-61134.

22. Anonymous (2005a). International Conference on Harmonisation; guidance on E14 Clinical Evaluation of QT/QTc Interval Prolongation and Proarrhythmic Potential for Non-Antiarrhythmic Drugs; availability. Notice. Fed Regist 70: 61134-61135.

23. CredibleMeds ${ }^{\circ}$ QTDrugs Lists [cited 05 August 2014]. Available: https://www.crediblemeds.org. Accessed 5 June 2016.

24. Schächtele S, Tümena T, Gaßmann KG, Fromm MF, Maas R. Co-Prescription of QT-Interval Prolonging Drugs: An Analysis in a Large Cohort of Geriatric Patients. PLoS One. 2016;11(5):e0155649. 
25. Vicente J, Johannesen L, Galeotti L, Strauss DG. Mechanisms of sex and age differences in ventricular repolarization in humans. Am Heart J. 2014;168(5):749-56).

26. Sumić JČ, Barić V, Bilić P, Herceg M, Sisek-Šprem M, Jukić V. QTc and psychopharmacs: are there any differences between monotherapy and polytherapy. Annals of General Psychiatry. 2007;6:13.

27. Sala M, Vicentini A, Brambilla P et al. QT interval prolongation related to psycho-active drug treatment: a comparison of monotherapy versus polytherapy. Ann Gen Psychiatry. 2005; 4:1.

28. Taylor DM. Antipsychotics and QT prolongation. Acta Psychiatr Scand. 2003;107(2):85-95.

29. Harrigan EP, Miceli JJ, Anziano R et al. A randomized evaluation of six antipsychotic agents on QTc, in the absence and presence of metabolic inhibition. J Clin Psychopharmacol. 2004; 24:62-9.

30. Curto M, Girardi N, Lionetto L, Ciavarella GM, Ferracuti S, Baldessarini RJ. Systematic Review of Clozapine Cardiotoxicity. Curr Psychiatry Rep. 2016;18(7):68.

31. Lam RW. Psychopharmacology for the Clinician. J Psychiatry Neurosci. 2013; 38(2): E5-E6.

32. Stringer J, Welsh Ch, Tommasello A. Methadone-associated Q-T Interval Prolongation and Torsades de Pointes. Am J Health Syst Pharm. 2009;66(9):825-833.

33. Viskin S, Rosovski U, Sands AJ, Chen E, Kistler PM, Kalman JM, Rodriguez Chavez L, Iturralde Torres P, Cruz
FFE, Centurion OA, Fujiki A, Maury P, Chen X, Krahn AD, Roithinger F, Zhang L, Vincent GM, Zeltser D: Inaccurate electrocardiographic interpretation of long QT: The majority of physicians cannot recognize a long QT when they see one. Heart Rhythm 2005;2: 569-574.

34. M.Vega, C. Riaza, A. Chinchilla, I. Gobernado. HYPOKALEMIA, PSYCHOMOTOR AGITATION AND PROLONGING THE QTC. European Psychiatry 2011.

35. Molnar J, Zhang F, Weiss J, Ehlert FA, Rosenthal JE. Diurnal pattern of QTc interval: how long is prolonged? Possible relation to circadian triggers of cardiovascular events. J Am Coll Cardiol. 1996;27(1):76-83.

36. Zitron E, Scholz E, Owen RW, Lück S, Kiesecker C, Thomas D, et al. QTc prolongation by grapefruit juice and its potential pharmacological basis: HERG channel blockade by flavonoids. Circulation. 2005;111:835-838.

37. Goldenberg I, Moss AJ, Zareba W. QT Interval: How to Measure It and What Is "Normal". J Cardiovasc Electrophysiol. 2006;17(3):333-6.

38. Ames D, Camm J, Cook P, Falkai P, Gury C, Hurley R, Johnson G, Piepho R, Vieweg V; Cardiac Safety in Schizophrenia Group. [Minimizing the risks associated with QTc prolongation in people with schizophrenia. A consensus statement by the Cardiac Safety in Schizophrenia Group]. Encephale. 2002; 28(6 Pt 1):552-62. 